А. П. Малецький ${ }^{1}$, Ю. М. Самченко ${ }^{2}$, В. В. Bim ${ }^{1}$, Н. М. Бігун ${ }^{3}$, Л. О. Керносенко ${ }^{2}$ ${ }^{1}$ ДУ «Інститут очних хвороб і тканинної терапії імені В. П. Філатова НАМН України» - м. Одеса, Україна,

${ }^{2}$ Інститут біоколоїдної хімії імені Ф. Д. Овчаренка НАН України - м. Київ, Україна,

${ }^{3}$ Львівська обласна клінічна лікарня МОЗ України - м. Львів, Україна

\title{
ОСОБЛИВОСТІ РЕАКЦІЇ М'ЯКИХ ТКАНИН ОРБІТИ I ВУШНОЇ РАКОВИНИ КРОЛИКІВ НА РОЗРОБЛЕНИЙ ГІДРОГЕЛЕВИЙ ІМПЛАНТАТ
}

\begin{abstract}
Мета дослідження - вивчити в експерименті особливості реакції м'яких тканин орбіти i вушної раковини на розроблений гібридний гідрогелевий імплантат на основі полівінілового спирту та акрилового гелю.

Матеріали та методи. В експерименті (на 8 кроликах) було вивчено особливості реакції м'яких тканин орбіти і вушної раковини та кісткових структур на розроблений нами гібридний гель.

Результати та їх обговорення. Розроблений гібридний гель має достатньо високу механічну міцність, пористість, що дозволяє забезпечити проникнення біологічних тканин в імплантат. Проведені патогістологічні дослідження на 10-у та 30-у добу показали, що навколо гібридного гелю як у склеральному мішку, так і в тканинах вушної раковини виникають наявні ознаки проростання навколишніх тканин у структуру матеріалу імплантата (формування навколо нього фіброзної капсули) та відсутність схильності його до резорбції.

Висновки. Гібридний гідрогель на основі полівінілового спирту та акрилової кислоти продемонстрував високу біосумісність із навколишніми біологічними тканинами та може бути рекомендований при виборі матеріалу імплантата.
\end{abstract}

Ключові слова: гібридний гель, імплантат, пластика, м'які тканини орбіти та вушної раковини.

В останні десятиліття помічається збільшення частоти краніо-фаціальних пошкоджень, основною причиною яких стають техногенні та кримінальні травми ока та орбіти [1]. За даними літератури, енуклеація та евісцерація очного яблука після проникаючої травми проводиться у 11,6-27,0 \% хворих [2, 3, 4, 6, 7, 8].

Застосування біологічних тканин в якості пластичного матеріалу не завжди задовольняє хірурга, крім того, з кожним роком збільшуються юридичні вимоги до одержання донорського матеріалу. Тому створення синтетичних полімерних матеріалів для відновлення анатомо-функціональних порушень є актуальним завданням.

Застосування в офтальмології силікону, поліетилену, політетрафторетилену та гідроксиапатитів показало, що вони недостатньо біосумісніі та не гарантують проростання в них біологічної тканини.

Принципово новими можливостями володіють небіологічні імплантати 3 пористою порожнистою структурою, які здатні до біоінтеграції з навколишніми орбітальними тканинами. Одним із них є гібридний гідрогель.
Гелі - це просторово-зшиті гідрофільні полімери, що вже протягом кількох десятиліть успішно використовуються в якості матеріалів для тканинної інженерії та пластичної хірургії [14], створення засобів для спрямованого транспорту лікарських препаратів [15], оптичних та аналітичних сенсорів і датчиків [12], матриць для біологічних досліджень [11] тощо. Аномально висока, у порівнянні $з$ твердими полімерами, біосумісність гелів 3 підвищеним рівноважним водовмістом насамперед зумовлена схожістю їх 3D структури з екстрацелюлярним матриксом [9].

Завдяки цьому гелі досить давно використовуються в різноманітних галузях пластичної хірургії, насамперед для протезування м'яких тканин людського організму. Так, поліакриламідний гель під різними торгівельними марками («Інтерфалл», «Фармакріл», «Контура» тощо) протягом багатьох років широко застосовувався для мамопластики та корекції форми губ. Широке застосування гелів у пластичній хірургії пояснюється насамперед їх високою біосумісністю, зумовленою схожістю їхньої структури 3 тканинами людського організму. Гелі мають високий рівноваж- 
ний водовміст, що може регулюватися у широких межах, м'якість, еластичність, можливість наповнення лікарськими препаратами з їх подальшим пролонгованим вивільненням. Сфера їхнього застосування, однак, часто обмежується недостатніми механічними властивостями гелів [10], а саме: низькою міцністю та еластичністю, а також крихкістю та ламкістю, зумовленими невисокою енергією руйнування традиційних гелів, яка складає близько 10 Дж/ $\mathcal{M}^{2}$ [13]. Подолати вказані обмеження можливо шляхом створення так званих гібридних гелів, які зконструйовані на основі взаємопроникних сіток двох полімерних матеріалів 3 різною природою. Отримані гібридні гелі позбавлені недоліків окремих вихідних компонентів та акумулюють їхні переваги.

Однак переважно гелі мають низьку механічну міцність, що обмежує можливість їхнього використання при протезуванні кісткових та хрящеподібних тканин. Досягти суттєвого покращання фізико-хімічних та експлуатаційних параметрів гелів здається можливим завдяки отриманню гібридного гелевого матеріалу на основі полівінілового спирту та акрилового гелю, чому і присвячено дане дослідження.

Мета дослідження - розробити гібридний гідрогель на основі полівінілового спирту та акрилового гелю, а також вивчити в експерименті особливості реакції м'яких тканин орбіти і вушної раковини на розроблений матеріал для імплантації.

Матеріали та методи. Для дослідження реакції м'яких тканин орбіти та тканини вушної раковини нами спільно із співробітниками Інституту біоколоїдної хімії НАН України (м. Київ) розроблено гібридний гель.

Гелі на основі акрилової кислоти (АК) були отримані шляхом радикальної полімеризації водного розчину мономерів (АК та $\mathrm{N}, \mathrm{N}^{\prime}$-метиленбісакриламіду (МБА)) при температурі $70^{\circ} \mathrm{C}$. Персульфат амонію (ПСА) був використаний для ініціювання реакції. Склад $\mathrm{pH}$-чутливих акрилових гідрогелів (ГГ) наведений у табл. 1. 3 детальним описом синтезу можна ознайомитися у нашій попередній роботі [5].

Після синтезу гелі відмивали від компонентів реакційної суміші, які не ввійшли в реакцію, у дистильованій воді при температурі $45^{\circ} \mathrm{C}$ протягом тижня. Воду міняли двічі на добу, а процес відмивання контролювали спектрофотометрично 3 використанням УФ-спектрометра SPECORD M40 (Carl Zeiss).

Матриці на основі полівінілформалю (ПВФ) були отримані обробкою полівінілового спирту формальдегідом у присутності сильної кислоти (табл. 2).

Гібридні матеріали на основі ПВФ та рН-чутливого гідрогелю отримували шляхом просочення губок ПВФ у гелеутворюючій композиції (табл. 1) протягом 5 хв. $з$ подальшим їх витримуванням в атмосфеpi інертного газу протягом 24 годин при температурі
Таблиия 1

Склад рН-чутливих гідрогелів на основі акрилової кислоти

\begin{tabular}{|c|c|}
\hline Компоненти & $\omega$, мас $\%$ \\
\hline АК & 9,9 \\
\hline МБА & 0,1 \\
\hline ПСА & 34,7 \\
\hline дистильована вода & 55,3 \\
\hline
\end{tabular}

Табличя 2

Склад пористої губки на основі ПВФ

\begin{tabular}{|c|c|}
\hline Компоненти & $\omega$, мас $\%$ \\
\hline ПВС & 9,1 \\
\hline формалін & 3,5 \\
\hline сульфатна кислота & 3,2 \\
\hline дистильована вода & 84,2 \\
\hline
\end{tabular}

$60^{\circ} \mathrm{C}$. Для отримання частково наповнених гібридних гелевих систем з відкритими транспортними порами відразу після просочення з губки видаляли частину гелеутворюючої композиції шляхом іiі віджимання при проведенні просочування у шприці. При цьому гібридні гелі позначали як ГГ-Х, де X - відносний вміст (об. \%) гелевої композиції у губці (після ії̈ просочення та віджимання) у порівнянні з повністю заповненою невіджатою губкою.

Аналіз функціональних груп акрилових гідрогелів, матриць на основі ПВФ та гібридних сорбентів проводили 3 використанням ІЧ-спектрометра Spectrum BX FT-IR (Perkin Elmer). Спектри реєстрували, використовуючи метод порушеного повного внутрішнього відбиття (спектроскопія внутрішнього відбиття) у діапазоні 550-4000 $\mathrm{cm}^{-1}$ із роздільною здатністю $2 \mathrm{~cm}^{-1}$. Для зменшення випадкових абсорбційних артефактів для кожного зразка було усереднено 8 ІЧ спектрів.

Детальну інформацію про структуру порового простору полімерних систем було отримано з аналізу мікрофотографій, зроблених з використанням скануючого електронного мікроскопа JSM-6060 LA (JEOL, Японія) 3 роздільною здатністю 4 нм. Підготовку зразків проводили 3 використанням сублімаційної установки УЗВ-10 (Харків, Україна). Для цього полімерні зразки висушували ліофільно, прикріпляли до стандартних тримачів за допомогою двосторонньої електропровідної плівки та покривали шаром $\mathrm{Au} /$ $\mathrm{Pd}$ товщиною 25 н $и$ у іонно-розпилюючій установці Gatan 682 Precision Etchingand Coating System (PECS) (Gatan). Фотографії отримували при використанні детектора вторинних електронів з енергією $10 \mathrm{keV}$.

Експериментальні дослідження проводились на базі віварію ДУ «Інститут очних хвороб і тканинної терапії імені В. П. Філатова НАМН України». Усі експериментальні дослідження проводилися з дотриманням етичних норм, передбачених міжнародними принципами Європейської конвенції «Про захист хребетних тварин, використовуваних для експери- 
ментів та в інших наукових цілях» (Страсбург, 1986р.) та норм біомедичної етики, схвалених першим національним конгресом України з біоетики (2001p.), а також Законом України № 3447-IV «Про захист тварин від жорстокого поводження» (Київ, 2006 р.).

Експериментальні дослідження були проведені на 8 кроликах породи «шиншила», масою $2-3 \kappa 2$, віком 5-6 міс., які під час дослідження знаходилися в однакових умовах перебування.

Для вивчення особливостей реакції м'яких тканин орбіти, вушної раковини на гібридний гель розміром $10,0 \times 10,0 \times 2,5$ мм він імплантувався у такі структури кроликів:

- у склеральний мішок;

- у тканини вушної раковини.

Хірургічні втручання виконувались під загальною анестезією (з розрахунком 1 мл 0,1 \% розчину тіопенталу натрію на 1 к2 маси тіла кролика внутрішньом’язово).

Першу групу склали 4 дослідні кролики, яким у склеральний мішок розміщався гібридний гель розміром 10,0×10,0×2,5 мм після попередньо проведеної евісцерації ока. На краї рани накладались вузлові шви (шовк № 6.0).

Другу групу склали 4 дослідні кролики, яким гібридний гель розміром $10,0 \times 10,0 \times 2,5$ мм імплантувався у м'які тканини вушної раковини після розсічення шкіри вушної раковини довжиною $13,0-15,0$ мм 3 наступним накладанням вузлових швів (шовк № 6.0) на краї рани.

Евтаназія тварин здійснювалась методом повітряної емболії під наркозом. Тварини виводились із дослідження безпосередньо після висічення імплантатів 3 навколишніми тканинами через 10, 30 і 60 діб.

Оцінка реакції м'яких тканин і кісткових структур на імплантуючі матеріали здійснювалась на основі аналізу змін клінічних і патоморфологічних показників.

Оцінка досліджуваних клінічних ознак (набряк тканин орбіти, щоки, вушної раковини, стан швів, наявність виділень) проводилась на 2-у, 5-у, 10-у і потім через кожні п’ять діб по бальній системі:

I. Набряк тканин орбіти (0 балів - набряк відсутній; 1 бал - набряк ділянки післяопераційного шва; 2 бали - набряк ділянки післяопераційного шва i прилеглої кон'юнктиви; 3 бали - виражений хемоз кон'юнктиви і набряк м'яких тканин орбіти).

II. Стан швів (0 балів - немає розходження швів; 1 бал - одинарні ділянки розходження швів до 1,0 мм; 2 бали - розходження швів більше 1,0 і менше 5,0 мм; 3 бали - розходження швів по всій довжині).

III. Виділення з кон'юнктивальної порожнини (0 балів - виділень немає; 1 бал - невелика кількість сукровичних виділень у кон'юнктивальній порожнині та на краях повік; 2 бали - незначне серозно-сукровичне виділення у кон'юнктивальній порожнині, на краях повік та орбітальній ділянці; 3 бали - виражене серозно-сукровичне виділення у кон'юнктивальній порожнині, на краях повік, орбітальній ділянці та за межами орбіти).

Патогістологічна оцінка тканин окуло-орбітальної ділянки, орбіти та тканини вушної раковини проводилась через 10 і 30 діб.

Фрагменти видалених тканин у ділянці імплантатів поміщались у 10 \%-й розчин формаліну на одну добу, а потім закріплювались у парафін. Гістологічні зрізи тканин зафарбовували гематоксилін-еозином на 5-й день і вивчали за допомогою мікроскопа Jenmed 2.

Результати та їх обговорення. Дослідження структури гібридного гелевого матеріалу. Як видно із скануючих електронних мікрофотографій полімерних сорбентів, ПВФ характеризуються добре розвиненою системою з'єднаних пор розміром менше 1 мM, а також наявністю пор із діаметром у декілька сотень мікрометрів. Варто також відзначити, що стінки ПВФ мають пористу структуру з приблизним діаметром пор 10 мкм та товщиною стінок у декілька мікрометрів. На відміну від ПВФ рН-чутливий гідрогель на основі ПАК має непористу структуру стінок значно меншої товщини (набагато менше 1 мкм), а також посідає систему ізольованих пор з діаметром близько 100 мкм. У випадку гібридного сорбенту структура порового простору подібна до ПВФ з невеликими відмінностями: пористість стінок менша, ніж у випадку ПВФ, що пояснюється полімеризацією у них гідрогелевої композиції, а також наявністю гелевих кластерів розміром приблизно 100-500 мкм у порах 3 діаметром менше 1,0 мм.

Функціональні групи ненаповнених пористих матриць на основі ПВФ, pН-чутливих гідрогелів на основі поліакрилової кислоти (ПАК) або гібридних матеріалів на основі ПВФ та ПАК були ідентифіковані, виходячи з отриманих ІЧ-спектрів. Для ненаповненого ПВФ (рис. 1a) у ІЧ-спектрі спостерігається широка смуга поглинання 3 максимумом у $3426 \mathrm{~cm}^{-1}$, яку ми віднесли до валентних коливань гідроксильної групи ОН. Збільшення цієї смуги та іiї зсув у низько частотну зону зумовлені утворенням водневих зв' язків між гідроксильними групами. У той же час абсорбція при $1008 \mathrm{~cm}^{-1}$ може бути віднесена до валентних коливань $\mathrm{C}-\mathrm{O}$ гідроксильної групи $(\mathrm{C}-\mathrm{OH})$ або $\mathrm{C}-\mathrm{O}-\mathrm{C}$ груп у шестичленному циклі з накладанням деформаційних коливань сусідніх $\mathrm{C}-\mathrm{C}$ зв'язків. У свою чергу наявність зазначених коливань може свідчити про присутність ланок полівінілового спирту у складі ПВФ.

Через сильну асоціацію за рахунок водневих зв'язків міжмолекулярні димери/«полімери» карбоксильної кислоти характеризуються наявністю дуже широкої та інтенсивної смуги 3 центром при $3050 \mathrm{~cm}^{-1}$, яка відповідає валентним коливанням гідроксильної групи 3 накладанням менш інтенсивних валентних 
коливань С-Н груп (рис. 1б). У спектрі ПАГ та ГГ смуга поглинання при 1698 та 1704-1717 $\mathrm{cm}^{-1}$ пов'язана із характеристичними коливаннями карбонільної групи $\mathrm{C}=\mathrm{O}$ (рис. 16,в). Для мономерної форми акрилової кислоти відповідна смуга спостерігається при $1732 \mathrm{~cm}^{-1}$, а її зсув у низькочастотну зону вказує на подальше збільшення ступеня асоціації карбоксильних груп за рахунок утворення водневих зв'язків. Також варто зазначити, що у спектрі ПВФ (рис. $1 a$ ) спостерігається низько інтенсивна смуга при $1735 \mathrm{~cm}^{-1}$, яку ми віднесли до валентних коливань карбонільної групи залишкових ацетатних груп.

Отже, детальний аналіз ІЧ-спектрів полімерних сорбентів підтвердив успішне включення $\mathrm{pH}$-чутливої ПАК до складу гібридного гелевого сорбенту та присутність у складі ПВФ і гібридного гелю на його основі залишкових гідроксильних, а також ацетатних груп.

Таким чином було розроблено методи синтезу гібридного гідрогелевого матеріалу, що поєднує та підсилює переваги вихідних компонентів.

Завдяки частковій віджимці гелеутворюючої композиції з поровидного простору губчатої полімерної матриці на основі ПВФ вдалося запобігти закорковуванню присутніх у ній відкритих та поєднаних транспортних пор, що дозволило забезпечити високу проникність гібридного матеріалу стосовно газів, рідин та біологічних тканин (рис. 2).

Експериментальні дослідження на кроликах показали, що в перші 5 діб після імплантації гібридного гелю в склеральний мішок і вушну раковину у всіх тварин спостерігався набряк ділянки післяопераційного шва і прилеглої кон'юнктиви, а також незначне серозно-сукровичне виділення із кон'юнктивальної порожнини. Після 5-ої доби відбувалося зменшення набряку та виділень 3 кон'юнктивальної порожнини, котрі минали на 8-у - 10-у добу.

Важливо зауважити, що при огляді післяопераційної рани шкіри і кон'юнктиви в перші доби і в наступні дні при імплантації гібридного гелю загоєння рани відбувалось первинним натягом.

Отриманий задовільний результат клінічної оцінки м'яких тканин орбіти та вушної раковини на імплантацію гібридного гелю дозволив оцінити реакцію клітинних структур на імплантат, наявність проростання навколишніх тканин в його структуру, а також схильність до резорбції.
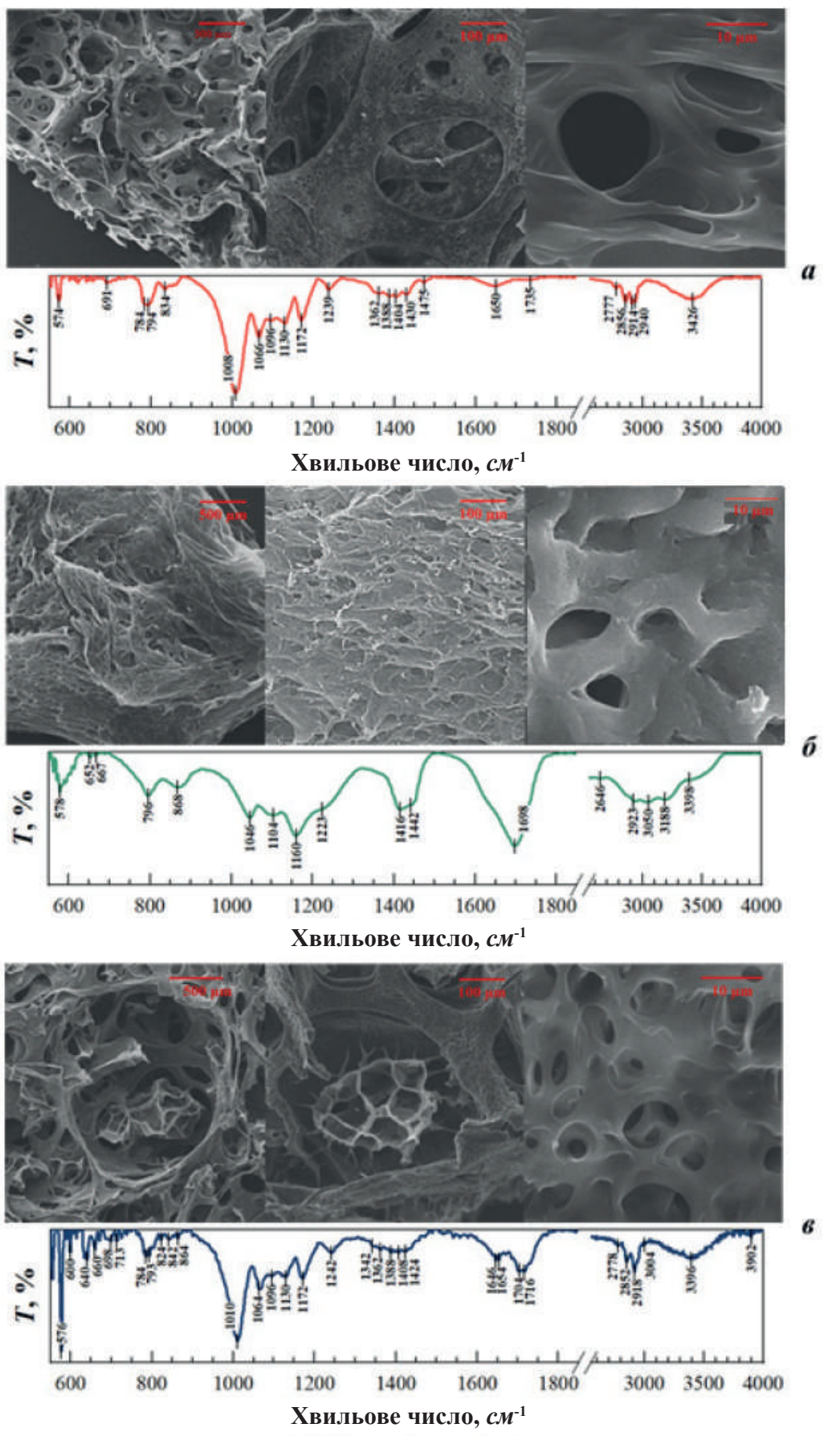

Puc. 1. Мікрофотографії та ІЧ-спектри сорбентів на основі ПВФ (a), pН-чутливого поліакрилового гідрогелю (б)

та гібридного гелю на їхній основі (6)

Патогістологічні дослідження показали, що через 10 днів після проведення оперативного втручання, яке передбачало розміщення імплантату (гібридний гель) в склеральний мішок, помічалась запальна інфільтрація склери та прилеглих до неї м'яких структур. При цьому в інфільтраті, окрім лімфоцитів, спостерігалася досить велика кількість еозинофільних лейкоцитів (рис. 3).

Важливо зауважити, що в більш периферичних ділянках склери відносно імплантату запальні явища були відсутні (рис. 3). 


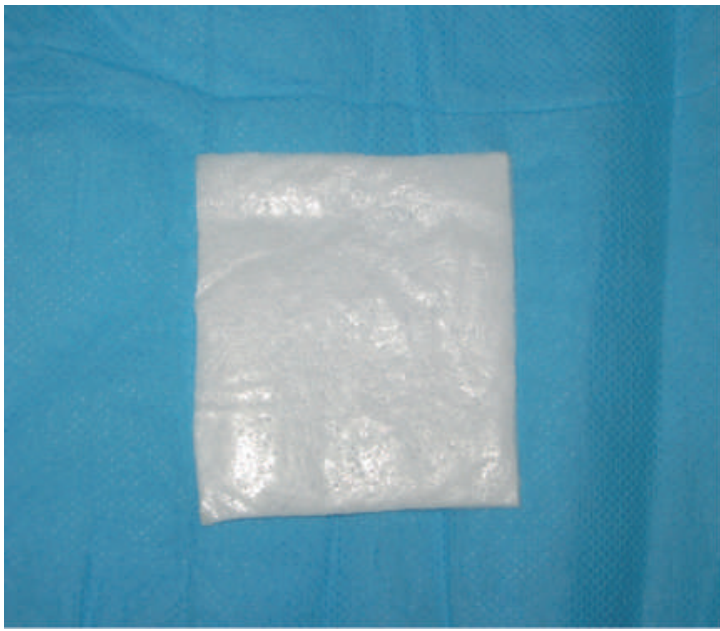

Рис. 2. Зовнішній вид гібридного гідрогелевого імплантату

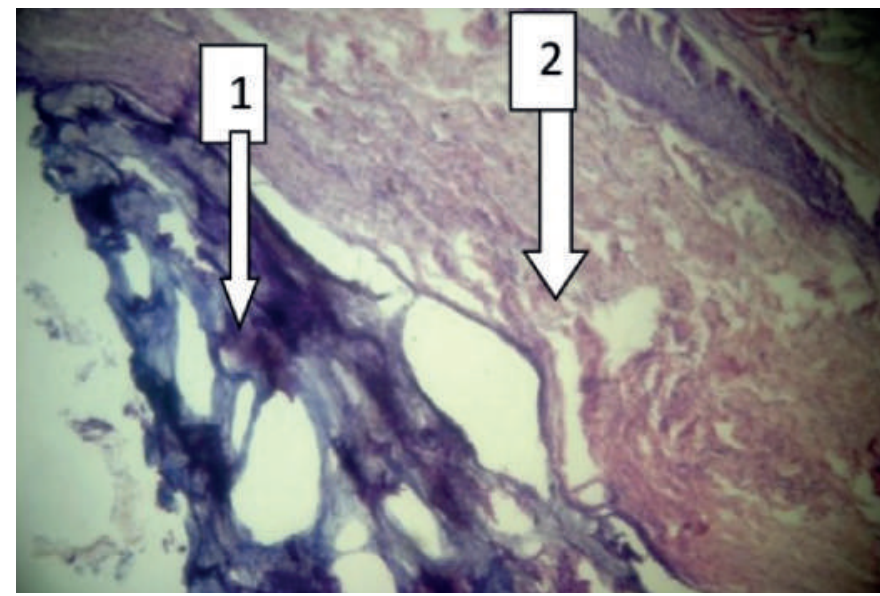

Puc. 4. 10-а доба після імплантації гібридного гелю у склеральний мішок (1 -імплантат; 2 - склера). (Гематоксилін-еозин; х 70)

Важливою вимогою до матеріалу, що імплантується, $є$ здатність до проростання навколишніх тканин у структури імплантату, а також схильність його до резорбції. Тому було доцільним вивчення впливу навколишніх біологічних тканин на сіткоподібну структуру імплантату (рис. 5).

На рис. 5 можна помітити, що структура імплантату зберігається, а по ходу перекладин відмічається формування ніжних пучків колагенових волокон, які незначно інфільтровані лімфоцитами. Склад «сотових» структур відсутній, можливо, в результаті гістологічної обробки.

У клінічній практиці виникає необхідність виповнення м'яких тканин після перенесених травм або видалення пухлин орбіти, повік та окуло-орбітальної ділянки. У зв'язку з цим було проведене вивчення взаємовідношення імплантату (гібридного гелю) з м'якими тканинами і хрящевими структурами. Патогістологічні дослідження показали, що при розміщенні імплантату в тканини вушної раковини через 10 діб навколо нього формується ніжна волокниста тканина, яка інфільтрована запальними клітинами (рис. 6, 7). При цьому зберігається слаб-

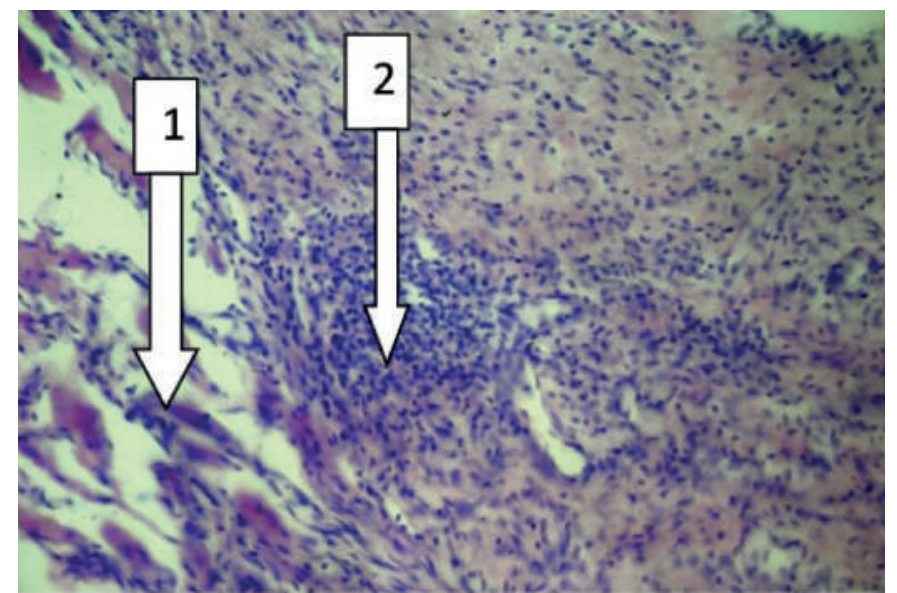

Puc. 3. 10-а доба після імплантації гібридного гелю в склеральний мішок (1 - імплантат; 2 - запальна інфільтрація склери). (Гематоксилін-еозин; х 120)

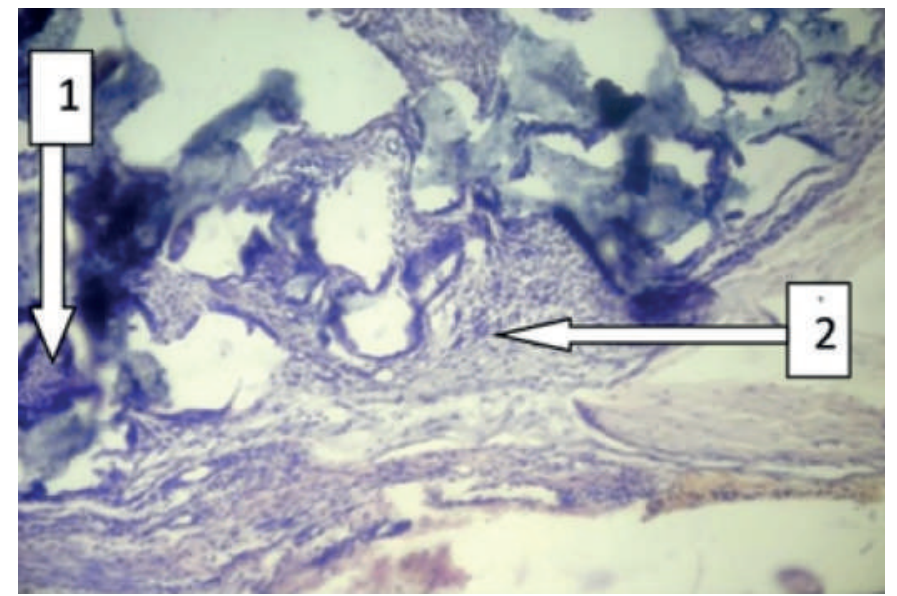

Рuc. 5. 10-а доба після імплантації гібридного гелю в склеральний мішок (1 - імплантат; 2 - фіброзна капсула). (Гематоксилін-еозин; х 70)

кий базофільний вміст «сотових» структур, а по перегородках помічаються початкові явища фібротизації.

Таким чином, оцінка клінічних ознак і результати патогістологічних досліджень після розміщення імплантату (гібридний гель) в склеральний мішок і тканини вушної раковини кролика дозволили зробити попередні висновки, які полягали в тому, що протягом 8-10 діб спостерігалась запальна реакція з боку тканин орбіти та вушної раковини, особливо перші 5 діб. Важливо зауважити, що в жодному випадку нами не було помічено оголення імплантата, а загоєння рани відбувалося первинним натягом. Патогістологічні дослідження показали, що навколо імплантату - як у склеральному мішку, так і в тканинах вушної раковини - наявні всі ознаки запалення (лімфоїдна та лейкоцитарна інфільтрація та ін.), а також продемонстрували наявність ознак проростання навколишніх тканин у структуру імплантату та відсутність схильності його до резорбції. Отримавши попередні дані, ми вирішили вивчити характер взаємодії імплантата (гібридний гель) з навколишніми тканинами у більш віддаленні строки (через 30 днів). 


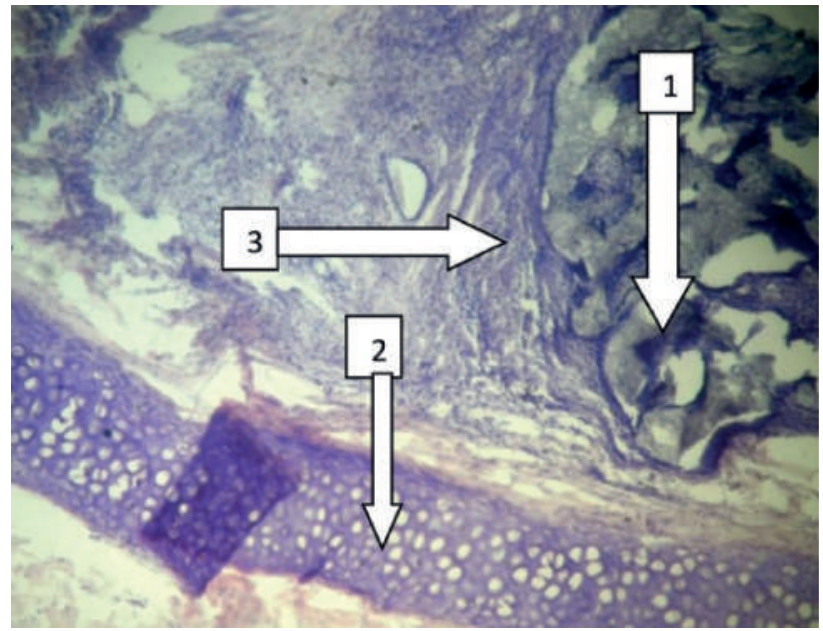

Puc. 6. 10-а доба після імплантації гібридного гелю в тканини вушної раковини (1 - імплантат;

2 - хрящ вушної раковини; 3 - волокниста тканина). (Гематоксилін-еозин; х 70)

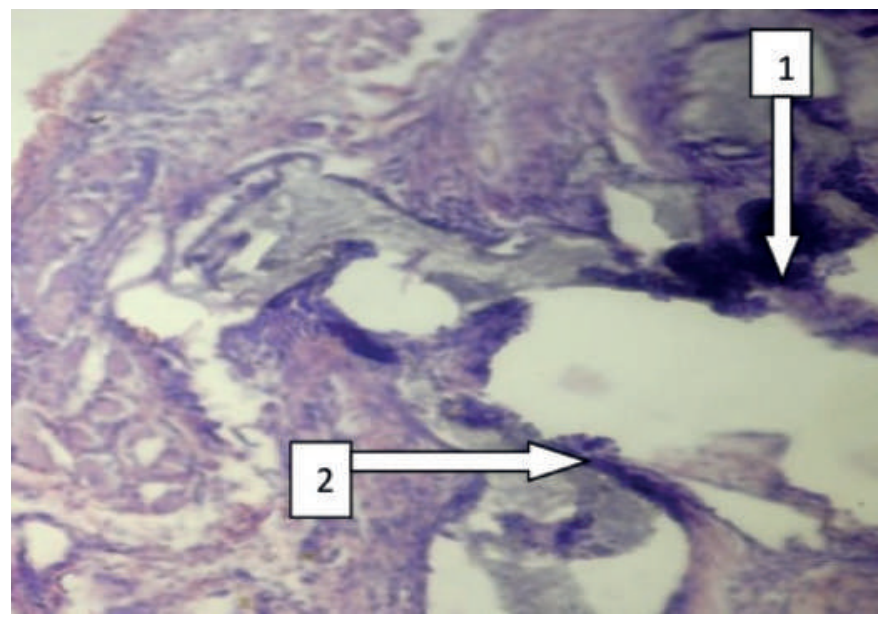

Puc. 8. 30 діб після імплантації гібридного гелю у склеральний мішок. Формування фіброзної капсули і масивне розростання волокнистої тканини по ходу перегородок «сотових» структур ( 1 - імплантат; 2 - розростання волокнистої тканини по ходу перегородок «сотових» структур). (Гематоксилін-еозин; х 180)

При розміщенні імплантату в склеральний мішок через 30 днів запальні явища навколо імплантату відсутні, але відмічалось формування фіброзної капсули з розповсюдженням фіброзної тканини по перегородках «сотових» структур. При цьому фіброзні прошарки досить грубі і не містять запальних елементів (рис. 8). До 30 доби вміст «сотових» структур визначається пристінково і в невеликій кількості.

Подібна патогістологічна картина спостерігалась через 30 днів також при імплантації гібридного гелю в тканини вушної раковини, яка полягала в фібротизації стінок «сотових» структур імплантату без наявності ознак запалення (рис. 9). Вміст «сот» відсутній в результаті гістологічної обробки матеріалу або можливої схильності до резорбції та їхньої заміни фіброзною тканиною.

Отримані результати експериментального дослідження, які стосуються вивчення характеру реакції

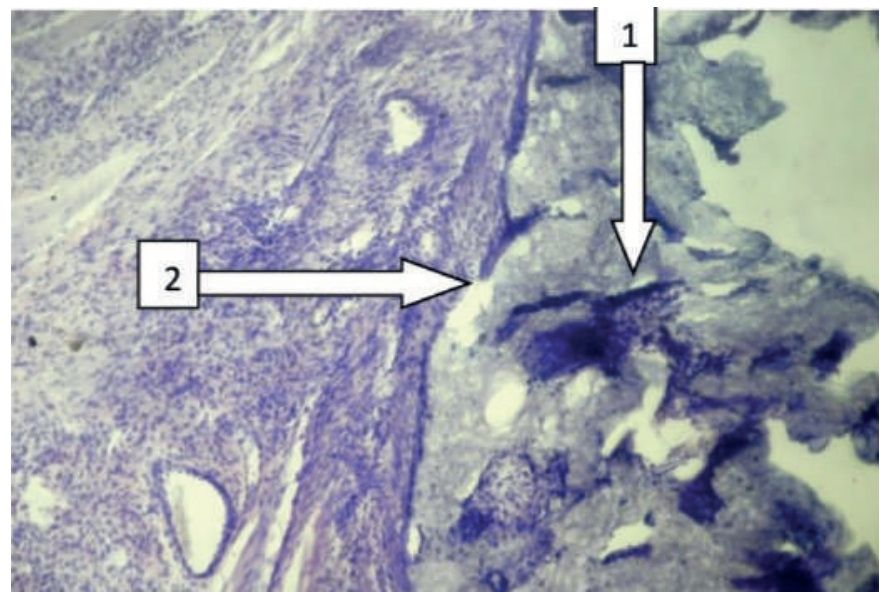

Рuc. 7. 10-а доба після імплантації гібридного гелю в тканини вушної раковини. Початкові явища проникнення волокнистої тканини по ходу перегородок «сотових» структур (1 - імплантат; 2 - волокниста тканина). (Гематоксилін-еозин; х 70)

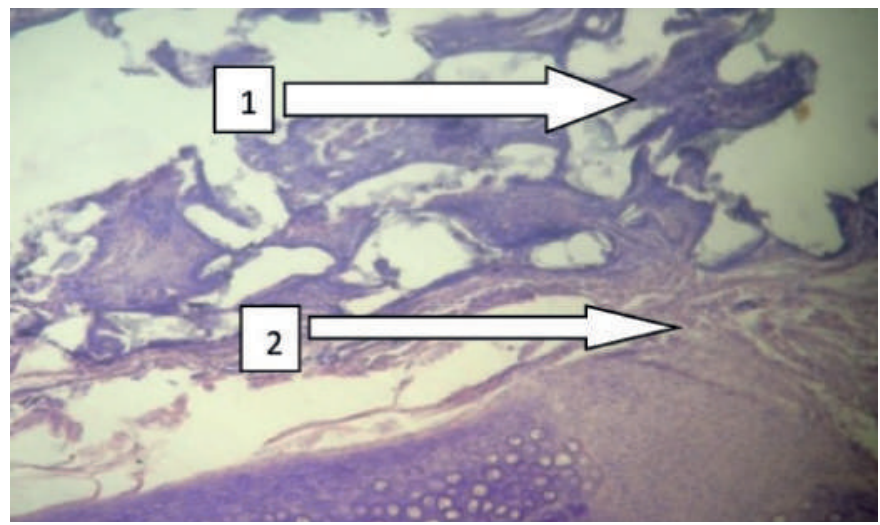

Рис. 9. 30 діб після імплантації гібридного гелю у вушну раковину кролика біля хрящевої пластинки (1 - імплантат; 2 - фібротизація стінок «сотових» структур імплантату). (Гематоксилін-еозин; х 70)

м'яких тканин кролика на імплантацію гібридного гелю в склеральний мішок і тканини вушної раковини, дозволили відповісти на ряд питань, котрі виникають при розробці матеріалів, що імплантуються.

Першою і найбільш важливою вимогою до імплантатів $є$ їхня біосумісність. Як показали наші дослідження, у всіх піддослідних кроликів спостерігалась помірна запальна реакція, яка зникала до 8-го - 10-го дня. Важливо зауважити, що у всіх групах досліджуваних тварин загоєння ран відбувається первинним натягом, а, отже, в жодному випадку не було оголення імплантату, що є дуже важливим позитивним показником для імплантатів. Проведені патогістологічні дослідження показали, що до 10-ої доби мають місце остаточні запальні явища близько до імплантату у вигляді лімфоїдної та лейкоцитарної інфільтрації, тоді як в більш віддалених ділянках відносно імплантату вони були відсутні.

Другим важливим показником, який ми відмітили, було проростання навколишніх тканин у структуру імплантату і формування до 10-ої доби після його 
імплантації ніжної фіброзної капсули (рис. 4), а на 30-у добу -масивної фіброзної капсули (рис. 7 і 8).

Третьою важливою перевагою імплантату є відсутність схильності його до резорбції, що дуже важливо для отримання стабільного клінічного результату.

Важливо також відзначити, що при розміщенні імплантату в м'які структури орбіти і вушної раковини нами не спостерігались зміни у кісткових структурах орбіти і в хрящевій пластині вушної раковини кролика.

\section{Висновки}

1. Розроблена гібридна гідрогелева композиція на основі полівінілового спирту та акрилового гелю має досить високу механічну міцність і пористість, що дозволяє забезпечити високу проникність біологічних тканин у матеріал.

2. При розміщенні імплантату з гібридного гелю у склеральний мішок і м'які тканини вушної раковини на ранньому післяопераційному стані (до 8-10 діб) відзначається помірне запалення оточуючих тканин. Загоєння рани відбувається первинним натягом, що свідчить про біосумісність матеріалу, який імплантується.

3. Імплантат 3 гібридного гелю зберігає свою структуру і не має схильності до резорбції через 30 діб після його імплантації в склеральний мішок i м'які тканини вушної раковини.

4. Починаючи з 10-ої доби після імплантації гібридного гелю, в його структури проростають оточуючі біологічні тканини і формується навколо нього фіброзна капсула, що $€$ важливим позитивним моментом при виборі для імплантації.

\section{Література}

1. Аніна С. І. Хірургічне та медикаментозне відновлення зору / С. І. Аніна, В. І. Левтюх // XII симпозіум офтальмол.: тези доп. - Чернівці, 2001. C. 8 .

2. Веселовська 3. Ф. Ефективність нової технології формування опорно-рухової культі після видалення очного яблука з застосуванням комбінованого імплантату / З. Ф. Веселовська, Н. М. Шадрина, Н. М. Веселовська // Офтальмол. журн. -2004. № 3. - C. 32-35.

3. Гундорова Р. А. Показания к удалению глазного яблока на основе анализа течения посттравматического увеита / Р. А. Гундорова, Е. Н. Вериго, В. А. Черноокова // Воспалительные заболевания органа зрения: научно-практ. конф.: тезисы докл. - Челябинск, 2004. - С. 95-98.
4. Красновид T. А. Об основных причинах удаления глазного яблока / Т. А. Красновид, Н. П. Тычина, Т. Н. Наровченко // 2-я Междунар. конф. офтальмологов Причерноморья, 8-10 сентября 2004 г.: тез. докл. - Одесса, 2004. - С. 147-148.

5. Крикля С. О. Гібридні $\mathrm{pH}-$ та термочутливі гідрогелі на основі полівінілового спирту та акрилових мономерів / С. О. Крикля, Ю. М. Самченко, В. В. Коновалова [та ін.] // Магістеріум. Хімічні науки. - 2016. - Вип. 63. - С. 20-28.

6. Сергиенко Н. М. Состояние и динамика слепоты и инвалидности вследствие патологии органа зрения в Украине / Н. М. Сергиенко, С. А. Рыков, Т. В. Крыжановская // Збірник наукових праць співробітників КМАПО ім. П. Л. Шупика. - Вип. 13, кн. 4. - Киев, 2004. - С. 582-586.

7. Филатова И. А. Причины и методы удаления глазного яблока по данным отдела травмы глаза института имени Гельмгольца / И. А. Филатова, Л. Я. Полякова // Восстановительное лечение при последствиях особо тяжелых повреждений органа зрения, полученных в чрезвычайных ситуациях: Сб. научн. работ. - М., 2002. - С. 44-46.

8. Яхницкая Л. К. Энуклеация в современной офтальмологии / Л. К. Яхницкая, В. Л. Красильникова, Ю. Д. Коваленко // Здравоохран. Беларуси. - 2001. - № 12. - С. 37-38.

9. Balakrishnan B. Biopolymer-based hydrogels for cartilage tissue engineering / B. Balakrishnan, R. Banerjee // Chem. Rev. - 2011. - Vol. 111. P. $4453-4474$.

10. Calvert P. Hydrogels for soft machines / P. Calvert // Adv. Mater. - 2009. - № 21. - P. 743-756.

11. Discher D. Growth factors, matrices, and forces combine and control stem cells / D. Discher, D. Mooney, P. Zandstra // Science. - 2009. - № 324. - P. 1673-1677.

12. Dong L. Adaptive liquid microlenses activated by stimuli responsive hydrogels / L. Dong, A. Agarwal, D. Beebe, H. Jiang // Nature. - 2006. - № 442. P. 551-554.

13. Lake $G$. The strength of highly elastic materials / G. Lake, A. Thomas // Proc R Soc A. - 1967. № 300. - P. 108-119.

14. Lee K. Hydrogels for tissue engineering / K. Lee, D. Mooney // Chem. Rev. - 2001. - № 7. - P. 18691879.

15. Qiu Y. Environment-sensitive hydrogels for drug delivery / Y. Qiu, K. Park // Ad Drug Delivery Rev. 2001. - № 3. - P. 321-339. 


\title{
ОСОБЕННОСТИ РЕАКЦИИ МЯГКИХ ТКАНЕЙ ОРБИТЫ И УШНОЙ РАКОВИНЫ КРОЛИКОВ НА РАЗРАБОТАННЫЙ ГИДРОГЕЛЕВЫЙ ИМПЛАНТАТ
}

\author{
А. П. Малецкий, Ю. М. Самченко, В. В. Вит, Н. М. Бигун, Л. А. Керносенко
}

Цель исследования - разработать гибридный гидрогель на основе поливинилового спирта и акрилового геля, а также изучить в эксперименте особенности реакции мягких тканей орбиты и ушной раковины при имплантации гибридного гидрогеля.

Материалы и методы. В эксперименте (на 8 кроликах) были изучены особенности реакции мягких тканей орбиты, ушной раковины и костных структур на разработанный нами гибридный гель.

Результаты и их обсуждение. Разработанный гибридный гель имеет достаточно высокую механическую прочность, пористость, что позволяет обеспечить прорастание биологических тканей в имплантат. Проведенные патогистологические исследования на 10 -е и 30 -е сутки показали, что вокруг гибридного геля как в склеральном мешке, так и в тканях ушной раковины имеются признаки прорастания окружающих тканей в структуру имплантируемого материала (формирование вокруг него фиброзной капсулы) и отсутствия склонности его к резорбции.

Выводы. Гибридный гель на основе поливинилового спирта и акриловой кислоты продемонстрировал высокую биосовместимость с окружающими биологическими тканями и может быть рекомендован при выборе имплантируемого материала.

Ключевые слова: гибридный гель, имплантат, пластика, мягкие ткани орбиты и ушной раковины.

\section{THE DEVELOPING OF THE HYBRID HYDROGEL WITCH BASED ON POLYVINYL ALCOHOL AND ACRYLIC GEL AND STUDY THE REACTION OF THE ORBITAL SOFT TISSUES AND AURICULAR CONCHA DURING THE EXPERIMENT TO THE DEVELOPED IMPLANT MATERIAL}

\author{
A. P. Maletskyy ${ }^{1}$, Y. M. Samchenko ${ }^{2}$, V. V. Vit ${ }^{1}$, N. M. Bigun ${ }^{3}$, L. O. Kernosenko ${ }^{2}$ \\ 1 "The Filatov Institute of Eye Diseases and Tissue Therapy of the National Academy \\ of Medical Sciences of Ukraine" \\ Odesa, Ukraine, \\ ${ }^{2}$ Institute of Biocolloidal Chemistry named after F. D. Ovcharenko of the Ministry of Public Health of Ukraine \\ Kyiv, Ukraine, \\ ${ }^{3}$ The Lviv District Hospital of the Ministry of Public Health of Ukraine \\ Lviv, Ukraine
}

Background. In view of the critical increase of craniofacial traumas, it becomes necessary to perform surgery repair of orbital and oculo-orbital region fractures. It should, however, be recognized that the modern ophthalmology artificial implants are not biocompatible enough. Non-biological implants with a porous structure, such as cross-linked hybrid gels are biological safe and biocompatible with surrounding tissues, which will allow to create new opportunities for their use.

Aim of the study. The purpose of the study is to develop a hybrid hydrogel based on polyvinyl alcohol and acrylic gel, as well as to study the soft orbital tissues and auricular concha reaction to the material for implantation during the experiment.

Materials and methods. As an implant, hybrid gel based on polyvinylformal and $\mathrm{pH}$-sensitive hydrogel was used, obtained by impregnating a spongy matrix in a gelling composition, synthesized by the radical polymerization of monomers in aqueous solution (acrylic acid and $\mathrm{N}, \mathrm{N}^{\prime}$-methylenebisacrylamide). The polymer obtained was characterized by modern physicochemical and optical methods of analysis. To study the characteristics of soft tissue reactions of orbital region, and bone structures to hybrid gel, the latter was implanted into the scleral sac and the ear tissue of rabbits. Evaluation of the response of soft tissues and bone structures to the implant was carried out on the base of analysis of clinical and pathomorphological studies.

Results. Methods of hybrid gel material (implant) which combines and enhances the advantages of the initial components have been developed.

Histological studies after implantation (on $10^{\text {th }}$ and $30^{\text {th }}$ days) revealed signs of germination of surrounding tissues both into the implanted structure (formation of a fibrous capsule) around the gel and into the scleral sac, and auricle tissues without inclination to resorption.

Conclusions. A hybrid gel based on polyvinyl alcohol acetals and acrylic acid demonstrated high biocompatibility with surrounding biological tissues, and can be recommended while choosing an implant material.

Key words: hybrid gel, biocompatible gel implant, oculoorbital area, scleral sac, tissue of auricular concha, orbit, reconstructive surgery.

Стаття надійшла до редакції 11.07.2018 p. 